\title{
Vocal Apparatus Structure of the Sarawak Frogs (Amphibia: Anura: Ranidae)
} (Struktur Alat Vokal Katak Sarawak (Amfibia: Anura: Ranidae))

\author{
ELVY QUATRIN DEKA, LELA SU’UT, HASNIZAM ABDUL W AHID \& RAMLAH ZAINUDIN*
}

\begin{abstract}
Studies have shown that some characters, such as morphological, biochemical and behavioural characteristics were shared among con-specifics of closely related frog species. It is hypothesized that closely related frogs would have similar vocal apparatus structure to produce similar call characteristics, in order to be recognized by con-specifics. The vocal apparatus structures of the frogs from Ranidae were, thus, investigated and calls were recorded from various locations in Sarawak, Borneo. The vocal apparatus was sliced and stained using haematoxylin and eosin staining method. The prepared slides were scanned using Dotslide System Olympus BX51. Captured images were further measured using Microscope Olympus BX51. The results showed that the vocal apparatus structure of ranids in Sarawak differed in length between pulvinar vocale and posterior margin ( be the most significant character to discriminate the Sarawak ranids. It is suggested that histological analysis is also a good method for study of phenotypic variation of frog species, as shown by the vocal apparatus structure of the anurans. This study provides an alternative method to differentiate taxonomic identity among frog species.
\end{abstract}

Keywords: Advertisement call; histological method; Ranidae; variations; vocal apparatus

\section{ABSTRAK}

Kajian terdahulu telah menunjukkan sesetengah ciri seperti morfologi, biokimia dan kelakuan dikongsi bersama antara spesies yang berkait rapat. Hipotesis menyatakan spesies katak yang berkait rapat akan mempunyai struktur alat vokal yang sama untuk menghasilkan bunyi panggilan yang sama untuk dikenali oleh individu daripada spesies berkenaan. Justeru, struktur alat vokal katak Ranidae telah dikaji dan bunyi panggilan telah dirakam dari beberapa tempat di Sarawak, Borneo. Alat vokal dipotong dan diwarna dengan kaedah pewarnaan hematoxilin dan eosin. Slaid yang telah disediakan diimbas dengan Dotslide System Olympus BX51. Gambar yang telah dirakam kemudian diukur menggunakan Mikroskop Olympus BX51. Keputusan menunjukkan bahawa struktur alat vokal ranid di Sarawak berbeza antara spesies pada jarak antara vokal pulvinar dan pinggir posterior (pvpm) atau dikenali sebagai kawalan peti suara, dan struktur ini adalah paling signifikan untuk membezakan ranid Sarawak. Ini telah menunjukkan bahawa analisis histologi merupakan satu kaedah yang bagus untuk mengkaji variasi finotaip spesies katak seperti pada struktur alat vokal katak. Kajian ini telah menyediakan satu kaedah alternatif yang boleh digunakan untuk membezakan identiti taksonomi antara spesies katak.

Kata kunci: Alat vokal; kaedah histologi; panggilan mengawan; Ranidae; variasi

\section{INTRODUCTION}

Acoustic signals produced by con-specific species of frogs effectively stimulate reproductive social behaviour of the frog. The signals may present the signaler's identity from characteristics, such as gender, type of species and maturity stage for reproduction of the con-specifics. However, some calls are often emitted for territory defence as well as to express distress when threatened. Vocalizations of frogs and in most vertebrates are highly developed and the call patterns vary among species in order to effectively inform the presence of an individual to others of the same species. The male call may vary in several components, for example, in spectral and temporal call characteristics as reported by McClelland et al. (1996). The extensive studies of frog call characteristics (Marquez \& Eekhout 2006; Matsui 1997; Sheridan et al. 2010; Zainudin et al.
2009) in the Sundaland region provide an opportunity to investigate variation in the vocal apparatus structure of each frog species. Furthermore, many studies previously were done on structures of vocal apparatus of frogs (Fears 2010; McClelland et al. 1996; Ryan 1990), but none on the vocal apparatus structure of the Sarawak ranids.

The vocal apparatus consists of cricoids ring, hyoid and related pairs of musculature type. The cricoids ring acts as a foundation of a house for arytenoids cartilages to attach to and to be pivoted (Duellman \& Trueb 1986). Some suggested that the structure of the cricoid cartilage and its processes are different among frog species. It also includes the extent and nature of the attachments between vocal apparatus and the arytenoids cartilage. The size and shape of vocal apparatus may reflect the way the vocal cord vibrates and it plays an important role in displaying 
fundamental and dominant frequency during frog call. This leads to the question of whether vocal apparatus structures vary among frog species and do these structures reflect their call characteristics? If so, can these variations discriminate frog species? It was hypothesized that the vocal apparatus of Sarawak frog species differ among species thus, reflects their differences in call characteristics of the frog's advertisement call. It is hoped that the study provides an alternative method that can be used to differentiate taxonomy identity among frog species.

\section{MATERIALS AND METHODS}

\section{SAMPLING PROCEDURES}

Field samplings were conducted throughout Sarawak divisions, comprising mixed dipterocarp forests at Gading National Park (N01 ${ }^{\circ} 41.495^{\prime}$ E109 $\left.50.927^{\prime}\right)$, Kubah National Park (N01³6'19.3” E110¹1'30.3”), Matang Wildlife Centre (N01³6'40.4" E11009'49.7”), Mulu National Park (N0403.021' E11451.399'), Batang Ai National Park (N01 ${ }^{\circ} 18.148^{\prime}$ E112 $\left.04.581^{\prime}\right)$ and Bako National Park (N01 ${ }^{\circ} 42.943^{\prime}$ E110 $\left.26.752 '\right)$. Frogs were sampled via Visual Encountering Signal (VES) and vocalization. Similar sampling methods were employed during each sampling period. Frogs were captured with bare hands and kept in plastic bags after completion of sound recording and brought back to the base camp. After the frog was euthanized, the vocal apparatus was dissected for preservation in $10 \%$ formalin solution. The specimens were then brought back to the Faculty of Medicine and Health Science, Universiti Malaysia Sarawak for laboratory analysis.

\section{HISTOLOGICAL WORK}

Histological protocol performed in this study was modified from Spector and Goldman (2006). The vocal apparatus specimens were sliced horizontally into pieces with a thickness of about 3-5 $\mathrm{mm}$ and approximately $30 \times 20 \mathrm{~mm}^{2}$ in dimension. Each specimen was cut at cross-section using a surgical blade and then placed in an embedding casket and labelled. The caskets were put in SAKURA Tissue-Tek VIP processor, where the tissues were dehydrated in ethanol, $\mathrm{HmbG}{ }^{\circledR}$ Chemicals $46.07 \mathrm{~g} / \mathrm{mol}$ $(99.98 \%)$ (to remove water from tissue), cleared in xylene, BDH $106.17 \mathrm{~g} / \mathrm{mol}$ microscopy is a process where miscible solution removes alcohol to allow melted paraffin wax to penetrate and impregnate a specimen. Completion of the above process was followed by embedding tissue in melted paraffin wax using SAKURA Tissue-Tek ${ }^{\circledR}$ TEC $^{\text {TM }}$ cryostat embedding machine. The tissue was placed in a steel mould containing melted paraffin wax. The melting point of paraffin wax used was normally between 56 and $58^{\circ} \mathrm{C}$. The paraffin was then left for hardening by freezing at $-5^{\circ} \mathrm{C}$ on the freezing plate. The block of wax provides support for cutting the specimen. The hard paraffin block containing the vocal apparatus was trimmed using a LEICA RM2255 microtome machine at $20.0 \mu \mathrm{m}$ thick and then sectioned at $3.0 \mu \mathrm{m}$.

Trimming and sectioning on the microtome was done using a microtome's steel blade. Blunt blades were not used but discarded. This is to avoid having unequal slices of the vocal apparatus which may lead to inaccurate measurements. The sliced sections were placed in warm water in a TBS (Triangular Biomedical Sciences) flotation bath where temperature was set at $50^{\circ} \mathrm{C}$ to allow the paraffin to spread. The sliced sections were fished out and adhered on a grease-free (of adhesive) glass slide. The slide was then labelled and left to dry in an oven at $60^{\circ} \mathrm{C}$ for half an hour or left at room temperature for an hour. Slides must be dried enough before staining to avoid the sectioned tissue from being trusted aside during rinsing. The tissue components stained with Hematoxylin and Eosin (H \& E) modified staining protocol from Kiernan (2008) (Table 1). The stained tissues were then mounted with glass cover slip (size $20 \times 40 \mathrm{~mm}$ ) using Microscopy DePeX (DPX) mounting medium (contains xylene; mixture of isomers and dibutyl phthalate) (BDH, Gurr; Prod361254D). The prepared slides were scanned under 40X magnification using a Dotslide System Olympus BX51 (Dotslide ${ }^{\circledR}$ Virtual Slide System). Digitized images were kept as file type -.vsi using Microscope Olympus BX51-Olypmus Image Capture Microscope (DP2-BSW) which can be opened with OlyviA version 2.2 XV 3.3 (Build 7669) - Olympus Soft Imaging Solutions GmbH software.

TABLE 1. H\&E staining protocols modified from Kiernan (2008)

\begin{tabular}{clc}
\hline No. & Step / Chemical & Duration \\
\hline 1 & Xylene I & $5 \mathrm{~min}$ \\
2 & Xylene II & $5 \mathrm{~min}$ \\
3 & Absolute Ethanol I & $5 \mathrm{~min}$ \\
4 & Absolute Ethanol II & $20 \mathrm{dips}$ \\
5 & Rinse with running water & $3 \mathrm{~min}$ \\
6 & Haematoxylin & $10 \mathrm{~min}$ \\
7 & Rinse with running water & $1 \mathrm{~min}$ \\
8 & $1 \%$ HCl & $2 \mathrm{dips}$ \\
9 & Rinse with running water & $1 \mathrm{~min}$ \\
10 & Weak ammonia & $3 \mathrm{dips}$ \\
11 & Rinse with running water & $1 \mathrm{~min}$ \\
12 & Eosin & $30 \mathrm{~s}$ \\
13 & $30 \%$ Ethanol & $10 \mathrm{dips}$ \\
14 & $50 \%$ Ethanol & $10 \mathrm{dips}$ \\
15 & $70 \%$ Ethanol & $10 \mathrm{dips}$ \\
16 & $95 \%$ Ethanol & $10 \mathrm{dips}$ \\
17 & $100 \%$ Ethanol & $1 \mathrm{~min}$ \\
18 & $100 \%$ Ethanol & $1 \mathrm{~min}$ \\
19 & Xylene I & $1 \mathrm{~min}$ \\
20 & Xylene II & $1 \mathrm{~min}$ \\
21 & Xylene III & $1 \mathrm{~min}$ \\
\hline
\end{tabular}




\section{MEASURING THE PREPARED SLIDES}

The micrographs were examined thoroughly following Mescher (2010) to differentiate each macromolecule component. The micrographs were measured in which linear and angle measurements were taken. Five landmark points were marked before measurement of each specimen was done: pulvinar vocale (pv); cardiac process of the cricoids (cp); bronchial process of the cricoids (bp); lateral process of the cricoids (lp); posterior margin of the arytenoids (pm); and esophageal process of the cricoids ring (ep) (Figure 1). Six linear measurements were taken from the landmark points, consisting of: distance between pulvinar vocale to the posterior margin of arytenoids (pvpm); distance between cardiac process of cricoids to the bronchial process of cricoids (cpbp); distance between bronchial process of cricoids to the lateral process of cricoids (bplp); distance between lateral process of cricoids to esophageal process of cricoids (lpep) and distance between cardiac process of cricoids to esophageal process of cricoids (cpep). These measurements represent the general shape of the vocal apparatus (length and width of the arytenoid cartilage and the cricoid ring). Two angle measurements were taken - bronchial process of cricoids measured from cardiac process of cricoids to esophageal process of cricoids $\left(\mathrm{bp}^{\circ}\right)$ and lateral process of cricoids measured from cardiac process of cricoids to esophageal process of the cricoids $\left(\mathrm{lp}^{\circ}\right)$. All measurements were digitized using DP2-BSW 2.1 (build 6207) and recorded (Table 2). All terminologies used in this study followed Fears (2010).

\section{DATA ANALYSIS}

Cluster analysis with UPGMA was employed using MultiVariate Statistical Package (MVSP ver 3.13d) to determine species grouping based on vocal apparatus measurements. Non-metric dimensional scale (NMDS) and discriminant factor analysis (DFA) were analysed via IBM SPSS Statistics version 21 to identify variables that can discriminate

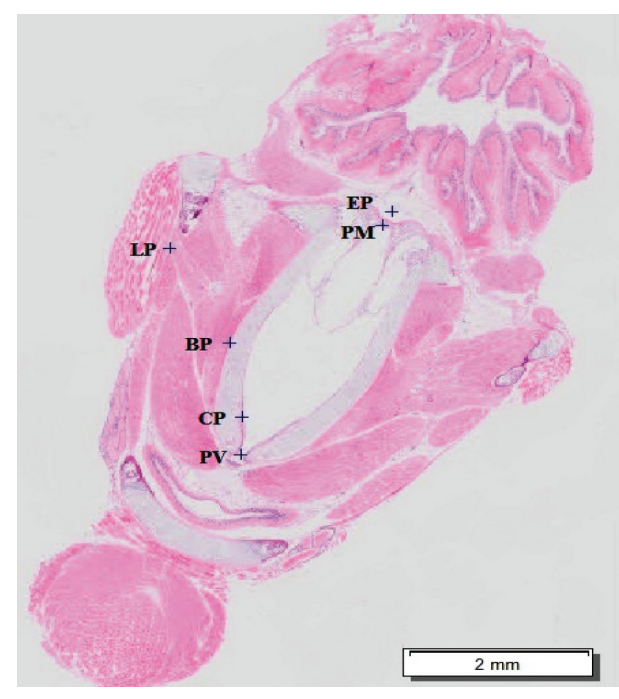

FIGURE 1. Six landmark points on the vocal apparatus of the frog. Each point was indicated as, PV - pulvinar vocale; CP cardiac process; BP - bronchial process; LP - lateral process; $\mathrm{PM}$ - posterior margin; EP - esophageal process

frog species based on the structure of vocal apparatus. A correlation matrix was also generated to determine the relationship of body size (snout-vent-length) with the vocal apparatus structure. The data were then analysed using Pearson's correlation coefficient with the significance level $p \leq 0.05$ or $p \leq 0.01$.

\section{RESULTS}

\section{STRUCTURES OF VOCAL APPARATUS}

A total of 27 individuals from 10 species of frogs were analysed in this study. The shape of each vocal apparatus was slightly varied across the frog species (Figure 2). Variation in the vocal apparatus would produce different call characteristics and this is consistent with Zainudin

TABLE 2. Mean data of the measured vocal apparatus (measurements in mm) with the frog's body size

\begin{tabular}{lcccccccc}
\hline Species ID & $\mathrm{pvpm}$ & $\mathrm{cpbp}$ & $\mathrm{cpep}$ & $\mathrm{bplp}$ & lpep & $\mathrm{bp}^{\circ}$ & $\mathrm{lp}^{\circ}$ & $\mathrm{svl}$ \\
\hline Hylarana glandulosa & 5.79 & 1.46 & 5.20 & 2.44 & 3.79 & 0.12 & 0.08 & 77 \\
Meristogenys phaeomerus & 1.27 & 0.41 & 1.18 & 1.26 & 1.46 & 0.10 & 0.04 & 37 \\
Staurois guttatus & 1.25 & 0.38 & 1.11 & 0.75 & 0.78 & 0.13 & 0.08 & 33 \\
Staurois latopalmatus & 1.08 & 0.41 & 1.11 & 1.11 & 1.29 & 0.10 & 0.05 & 44 \\
Huia cavitympanum & 3.64 & 1.27 & 3.64 & 1.74 & 2.88 & 0.11 & 0.08 & 45 \\
Hylarana baramica & 3.27 & 0.73 & 2.94 & 1.74 & 1.70 & 0.13 & 0.09 & 45 \\
Hylarana raniceps & 2.60 & 0.48 & 2.30 & 1.12 & 1.32 & 0.16 & 0.11 & 31 \\
Hylarana luctuosa & 2.22 & 1.22 & 2.05 & 0.65 & 1.89 & 0.09 & 0.07 & 55 \\
Hylarana signata & 2.56 & 0.71 & 2.23 & 1.34 & 1.92 & 0.13 & 0.07 & 37 \\
Hylarana picturata & 2.76 & 0.62 & 2.49 & 1.88 & 1.84 & 0.13 & 0.07 & 48
\end{tabular}

pvpm - Distance between pulvinar vocale to the posterior margin of arytenoids; cpbp - Distance between cardiac process of cricoids to the bronchial process of cricoids; bplp - Distance between bronchial process of cricoids to the lateral process of cricoids; lpep- Distance between lateral process of cricoids to esophageal process of cricoids; cpep - Distance between cardiac process of cricoids to esophageal process of cricoids; bp ${ }^{\circ}$ - Bronchial process of cricoids measured from cardiac process of cricoids to esophageal process of cricoids; $1 p^{\circ}$ - lateral process of cricoids measured from cardiac process of cricoids to esophageal process of the cricoids; and svl - snout vent length (total length of the body) 
et al. (2009) who suggested that the advertisement call characteristics are good characters for species recognition. Three Hylarana species, i.e. Hylarana baramica, $H$. glandulosa and $H$. raniceps, showed the most identical shape as shown in Figure 2(b), 2(c) and 2(g), respectively. Zainudin et al. (2009) suggested that call characteristics were similar among closely related species and this also reflected in their vocal apparatus structure. However, among all species of the Hylarana group examined in this study, the vocal apparatus structure observed in Hylarana luctuosa showed the most distinct structure, as it possessed two empty halls on each side of the arytenoids cartilages (Figure 2(d)). This structure might contribute to the sound production of $H$. luctuosa that produced a single muted sound with increasing note, a cat-like call, described as 'meow' in Zainudin et al. (2010a). On the other hand, the most distinctive shape of the vocal apparatus belonged to
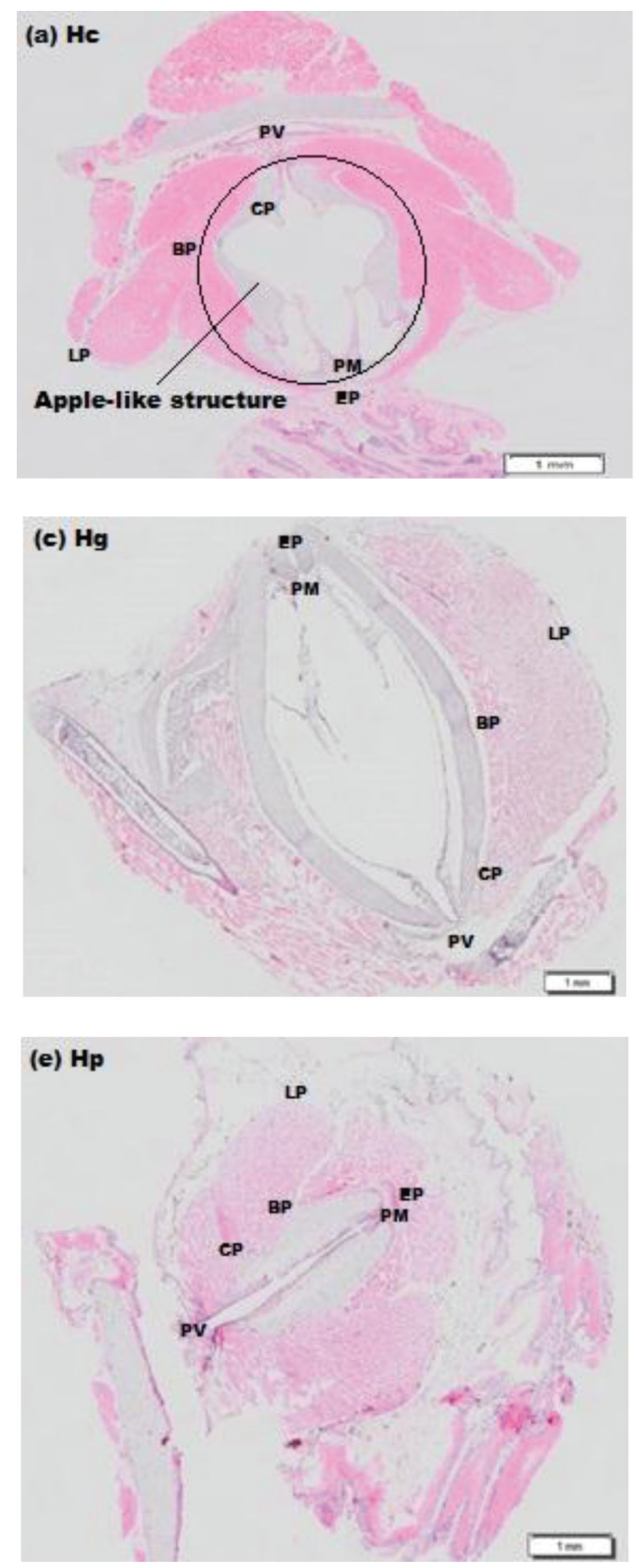

Huia cavitympanum (Figure 2(a)) that showed an applelike structure with more empty space or hall for the air to fill during vocalization. This finding may explain the complicated medium used for this species to emit pure ultrasonic signals in nature as reported by Arch et al. (2008). The thickness of arytenoids surrounding muscles also influence the temporal call characteristics, as the muscles control the movement of arytenoid cartilages. This could be seen in the vocal apparatus of Meristogenys phaeomerus (Figure 2(h)) and Staurois latopalmatus (Figure 2(j)).

\section{SIMILARITY OF VOCAL APPARATUS AMONG GENERA}

A dendrogram (Figure 3) showed that three clusters were apparent based on similarities of the vocal apparatus at generic level. The first cluster (C1) showed that only Hylarana glandulosa was grouped distinctively from the
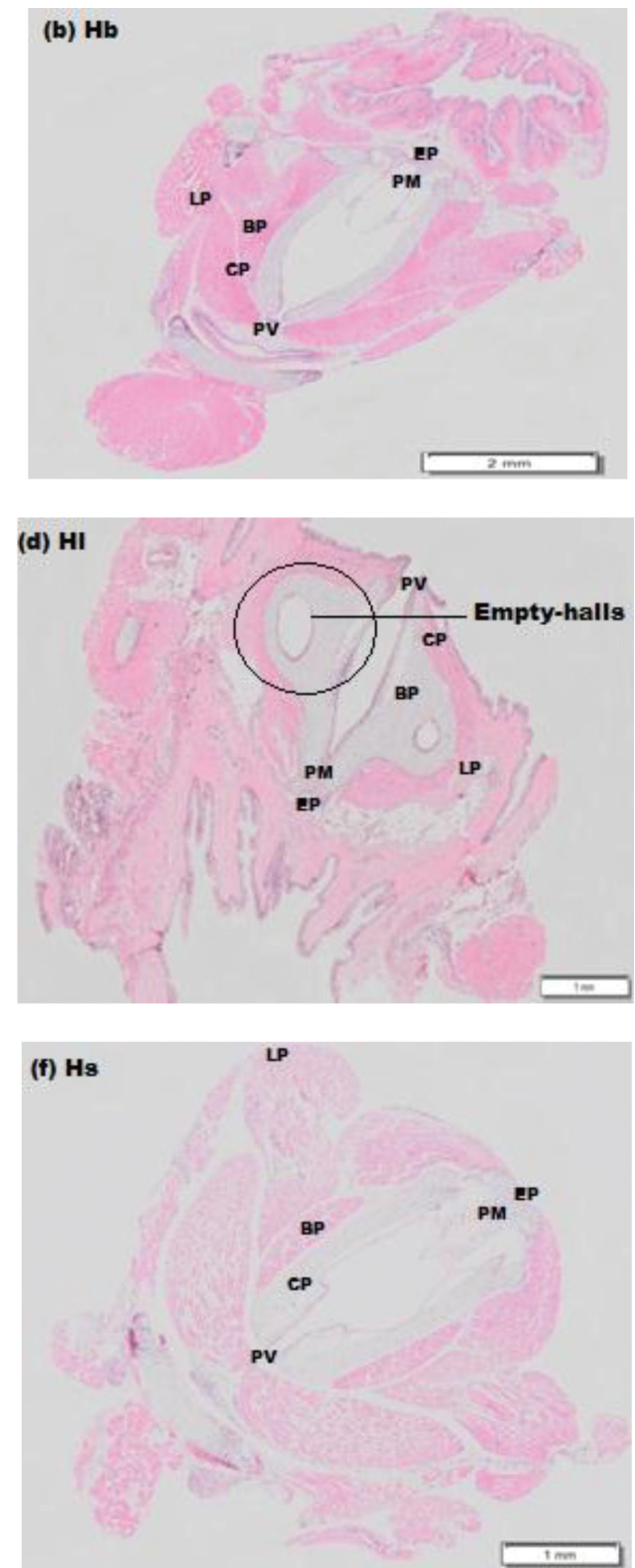

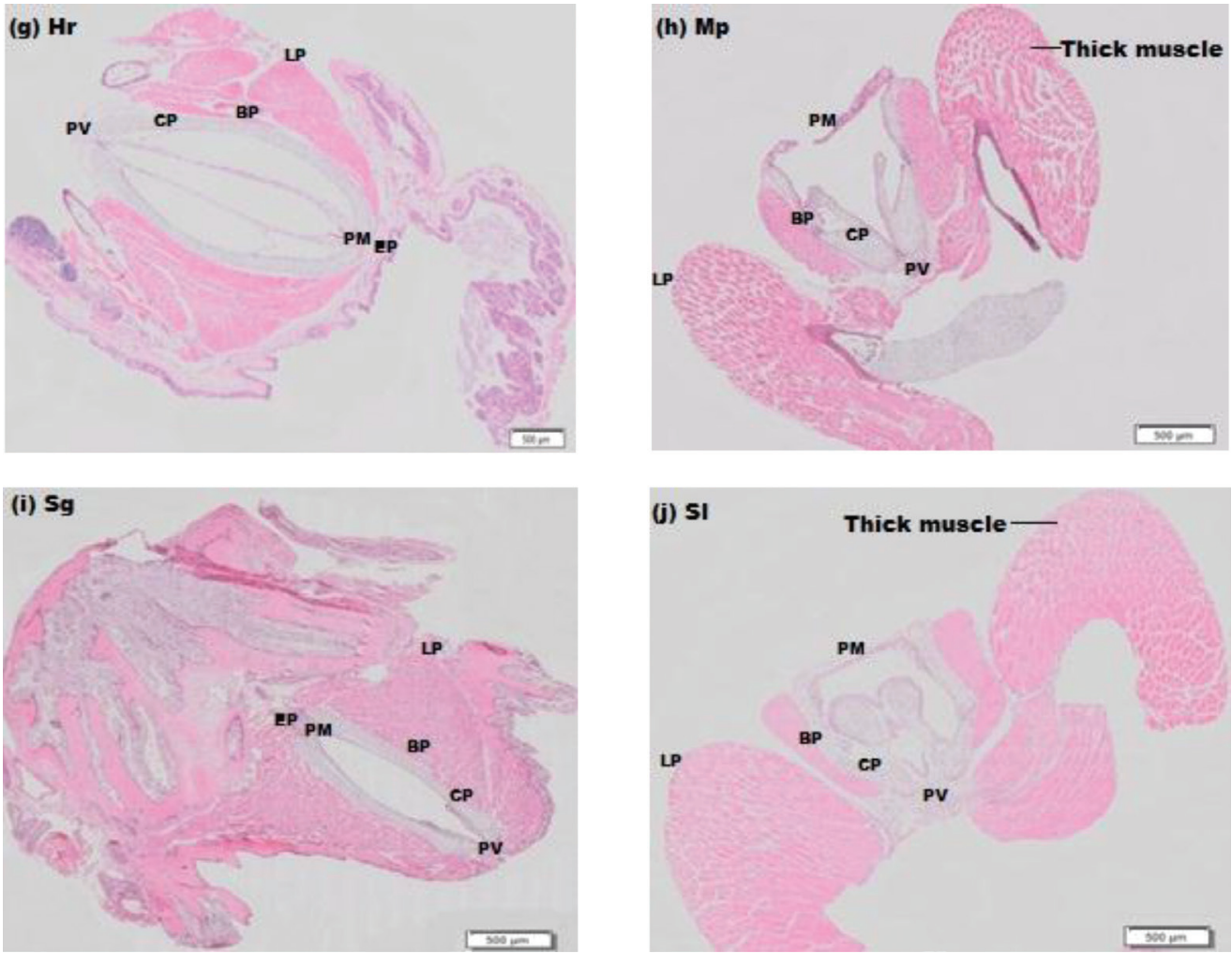

FIGURE 2. Micrographs of the vocal apparatus for each frog species under study (a) Huia cavitympanum, (b) Hylarana baramica,

(c) Hylarana glandulosa, (d) Hylarana luctuosa, (e) Hylarana picturata, (f) Hylarana signata, (g) Hylarana raniceps, (h) Meristogenys phaeomerus, (i) Staurois guttatus and (j) Staurois latopalmatus

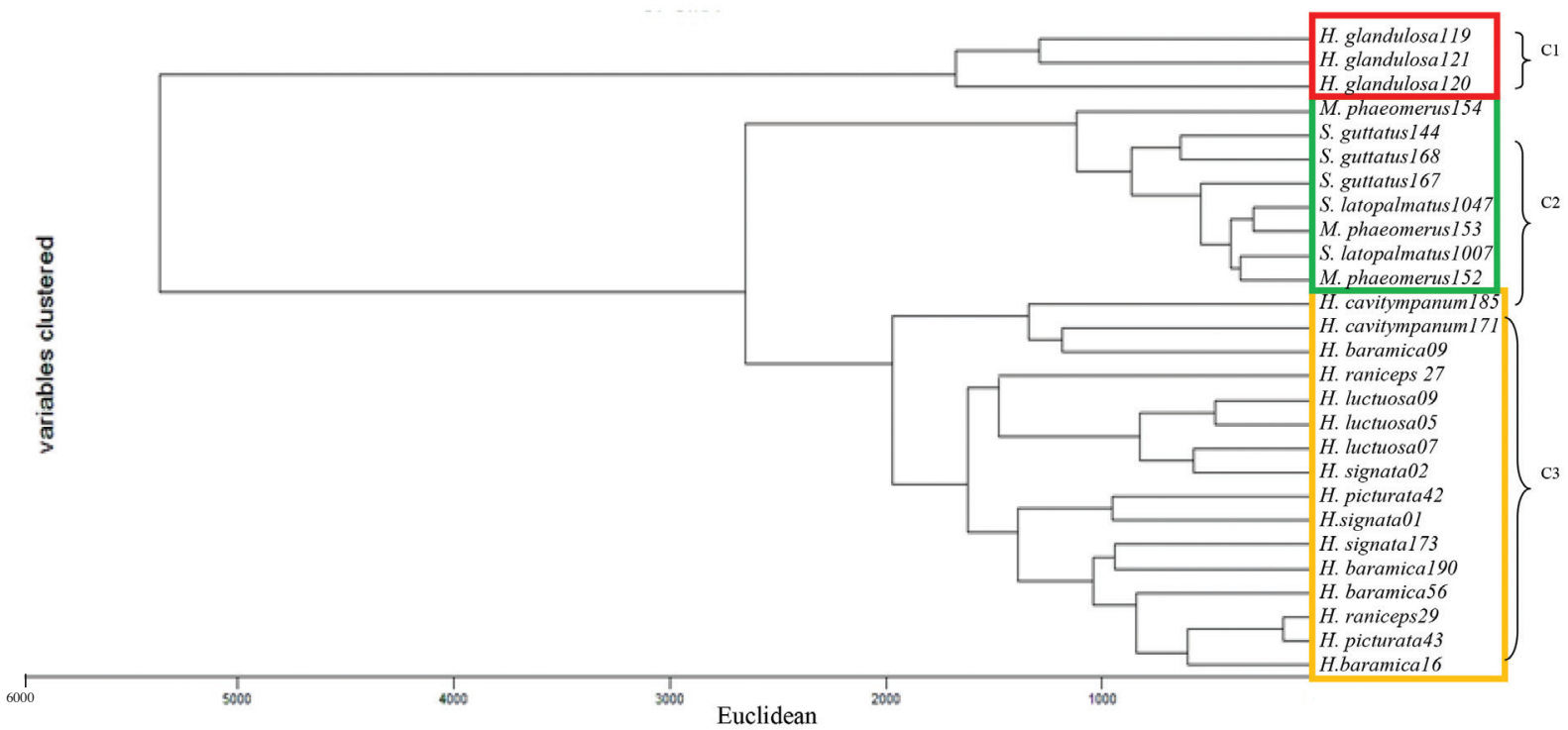

FIGURE 3. Dendrogram of cluster analysis using UPGMA analysis and average Euclidean distance method C1: Cluster 1 (Hylarana glandulosa); C2: Cluster 2 (Meristogenys phaeomerus, Staurois guttatus and Staurois latopalmatus); C3: Cluster 3 (Huia cavitympanum, Hylarana baramica, Hylarana raniceps, Hylarana luctuosa, Hylarana signata and Hylarana picturata)

other species of group Hylarana (Cluster C3). This may be due to its larger body size that contributes to the size of the vocal apparatus. Thus, this result had supported Zainudin et al. (2010a) in which Hylarana body size did influence the advertisement call characteristics. The other genera (Staurois and Meristogenys) were in Cluster 2 (C2), which comprised of three species - Staurois guttatus, S. latopalmatus and M. phaeomerus. These frogs were normally found at fast flowing streams, dwelling on rocks and overhanging vegetation. The modification of 
their vocal apparatus structure enables these species to deliver acoustic signals to their conspecifics against the loud background noise from the streams. This finding is consistent with Wollerman (1999). Another species that shows similar modification is the endemic Bornean frog, which inhabits at the northern part of Malaysian Borneo (Inger \& Stuebing 2005), known as Huia cavitympanum. This species was grouped in Cluster 3 together with the other Hylarana species and differed from the rest by having a sunken tympanum that reflects the adaptation of receiving an ultrasonic sound (Mason et al. 2010, 2009; Narins 2009). Huia cavitympanum is the only known Sarawak frog species that can produce a pure ultrasonic signal (Arch et al. 2008). It is one of their modifications to adapt well with their loud background noise of fast flowing stream they inhabit in the wild for successful communication. The ability to produce ultrasonic signal by this species may be strongly influenced by the distinct vocal apparatus structure they possess (apple like structure) with evidence that they cluster on its own group. Overall, the result indicated that the vocal apparatus structures are useful for grouping the Sarawak ranids.

\section{IDENTIFICATION OF UNIQUE HISTOLOGICAL CHARACTERS}

The results above can only differentiate vocal apparatus by their similarities. In order to determine significant characters which actually discriminate these frogs, discriminant function analysis (DFA) was employed. Two dimensions were derived to show the relationship of vocal apparatus characters for Sarawak Ranidae using nearest scaling with low stresses (Stress- $1=0.035$, Stress- $2=$ 0.064 , S-stress $=0.001$ ) and high coefficient (Tucker's coefficient of congruence $=0.999$ ) in NMDS. This indicates that data of the vocal apparatus character measurements were sufficient for discrimination of the Sarawak ranids. Only one out of seven total measurements of the vocal apparatus characters were meaningful (Table 3; Figure 4(a), 4(b)) to differentiate vocal apparatus structures of the Sarawak ranids. Four positive loadings (Table 3; Figure 4a) of dimension 1 indicated that four variables are useful to differentiate vocal apparatus structure among the frog species. The variables are linear measurements of pulvinar vocale to posterior margin of arytenoid cartilage (pv-pm), cardiac process to esophageal process (cp-ep), bronchial process to lateral process of cricoid ring (bp-lp) and lateral process of cricoid ring to esophageal process (lp-ep). Dimension 2, on the other hand indicated two negative loadings; linear measurements from bronchial process to lateral process of cricoid ring (bp-lp) and from lateral process of cricoid ring to esophageal process (lp-ep) with one positive loading of linear measurement from pulvinar vocale to posterior margin of the arytenoids cartilage (pvpm) as shown in Table 3 and Figure 4(b). Both dimensions 1 and 2 showed high positive values at 0.913 and 0.261 , respectively, indicating that linear measurement of the vocal apparatus from pulvinar vocale to posterior margin of the arytenoids cartilage was the most useful character of the vocal apparatus structure for each species in family Ranidae. Nevertheless, dimension 1 showed that the angle measurements were not suitable or not preferred to differentiate the structures. Thus, the angle measurement was not a good character to identify the vocal apparatus for each species.

Discriminant Factor Analysis (DFA) showed that the eigenvalue of Function 1 was 48.062 with variance percentage of $86 \%$, indicating that Function 1 was the highest variability of characters among the Sarawak frogs. Functions 2 and 3 had eigenvalues 6.319 and 1.204, with 11.3 and $2.2 \%$ of variance, respectively. The other three functions, Functions 4, 5 and 6, showed very low eigenvalues suggesting low variability of the functions (Table 4). Table 5 shows the significant test of this analysis based on the Wilk's Lambda and p-value. The Wilk's Lambda for the test of Function 1 through Function 6 showed high significant value 0.000 with Wilk's Lambda value was 0.001 , supported by the value in standardized discriminant function coefficients (Table 6). For Function 1 , the highest value was heavily loaded by variable of pvpm (1.348), suggesting that the length between pulvinar vocale and posterior margin (pvpm) was the vocal cord stricter

TABLE 3. Final coordinates of two dimensions for each vocal apparatus measurements of Bornean Ranidae. FCD1 = Final coordinate dimension $1 ; \mathrm{FCD} 2=$ Final coordinate dimension 2

\begin{tabular}{cllcc}
\hline No. & Vocal apparatus measurements & Code & FCD1 & FCD2 \\
\hline 1 & $\begin{array}{l}\text { Linear measurement from pulvinar vocale to posterior margin of arytenoid } \\
\text { cartilage }\end{array}$ & pvpm & 0.913 & 0.261 \\
2 & Linear measurement from cardiac process to bronchial process of cricoid ring & cpbp & -0.188 & -0.016 \\
3 & Linear measurement from cardiac process to esophageal process & cpep & 0.845 & 0.085 \\
4 & Linear measurement from bronchial process to lateral process of cricoid ring & bplp & 0.338 & -0.181 \\
5 & Linear measurement from lateral process of cricoid ring to esophageal process & lpep & 0.673 & -0.263 \\
6 & $\begin{array}{l}\text { Angle measurement }\left({ }^{\circ}\right) \text { of the bronchial process measured from cardiac process } \\
\text { to esophageal process of cricoids }\end{array}$ & bp & -0.625 & 0.026 \\
7 & $\begin{array}{l}\text { Angle measurement }\left({ }^{\circ}\right) \text { of the lateral process measured from cardiac process to } \\
\text { esophageal process of cricoids }\end{array}$ & lp & -0.644 & 0.035 \\
\hline
\end{tabular}


(a) Final Coordinate Dimension 1 of Vocal Apparatus Family Ranidae

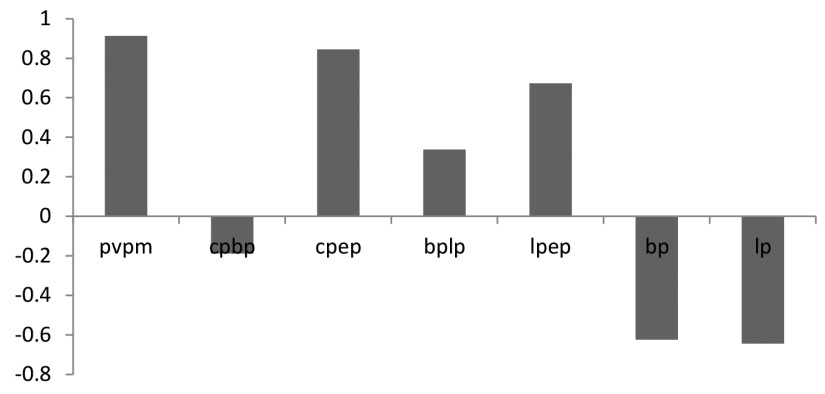

(b) Final Coordinate Dimension 2 of Vocal Apparatus Family Ranidae

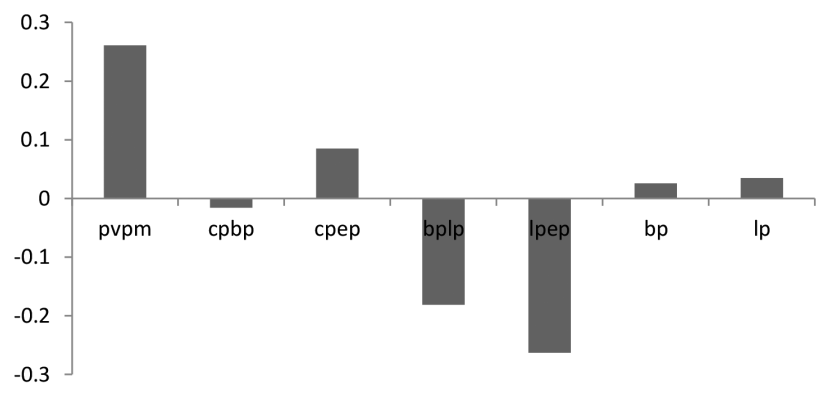

FIGURE 4. (a) Final coordinate dimension 1 of vocal apparatus of family Ranidae and

(b) Final coordinate dimension 2 of vocal apparatus of family Ranidae

TABLE 4. Eigenvalues of six functions in DFA

\begin{tabular}{ccccc}
\hline Function & Eigenvalue & \% of variance & Cumulative $\%$ & Canonical correlation \\
\hline 1 & $48.062^{\mathrm{a}}$ & 86.0 & 86.0 & 0.990 \\
2 & $6.319^{\mathrm{a}}$ & 11.3 & 97.3 & 0.929 \\
3 & $1.204^{\mathrm{a}}$ & 2.2 & 99.4 & 0.739 \\
4 & $0.224^{\mathrm{a}}$ & 0.4 & 99.8 & 0.428 \\
5 & $0.69^{\mathrm{a}}$ & 0.1 & 100.0 & 0.254 \\
6 & $0.26^{\mathrm{a}}$ & 0.0 & 100.0 & 0.158 \\
\hline
\end{tabular}

a. First 6 canonical discriminant functions were used in the analysis

TABLE 5. The Wilk's lamda test of six functions

\begin{tabular}{lcccc}
\hline Test of Function(s) & Wilk's Lambda & Chi-square & df & Sig. \\
\hline 1 through 6 & 0.001 & 83.608 & 42 & 0.000 \\
2 through 6 & 0.046 & 36.891 & 30 & 0.180 \\
3 through 6 & 0.338 & 13.006 & 20 & 0.877 \\
4 through 6 & 0.745 & 3.525 & 12 & 0.991 \\
5 through 6 & 0.912 & 1.101 & 6 & 0.981 \\
6 & 0.975 & 0.302 & 2 & 0.860 \\
\hline
\end{tabular}

that can significantly discriminate among the Sarawak ranids. Figure 5 shows two different groups indicating that this unique characteristic successfully discriminate frog species of Sarawak based on the size of their vocal apparatus which is relative to the body size of the frog.

\section{UNIVARIATE CORRELATIONS}

The correlation analysis of body size and vocal apparatus measurements indicated that body size, measured from snout to vent (SVL), strongly correlated with the morphological structure of the vocal apparatus (Table 
TABLE 6. Standardized canonical discriminant function coefficients

\begin{tabular}{lcccccc}
\hline & \multicolumn{5}{c}{ Function } & \\
& 1 & 2 & 3 & 4 & 5 & 6 \\
\hline pvpm & $\mathbf{1 . 3 4 8}$ & -0.141 & 0.438 & 0.249 & 0.431 & 0.418 \\
cpbp & 0.652 & 1.024 & $\mathbf{0 . 8 9 9}$ & 1.223 & -0.148 & 0.145 \\
cpep & -1.059 & -2.556 & -1.180 & -1.659 & -1.506 & -0.868 \\
bplp & 0.736 & 1.968 & -0.245 & $\mathbf{1 . 7 2 3}$ & 0.745 & -0.403 \\
lpep & 0.615 & 2.556 & 0.581 & 0.528 & 1.152 & $\mathbf{0 . 7 6 6}$ \\
bp & 0.016 & 0.766 & 0.005 & -0.226 & -0.619 & 0.621 \\
lp & 0.683 & $\mathbf{3 . 9 9 6}$ & 0.706 & 1.585 & $\mathbf{1 . 4 0 7}$ & -0.503 \\
\hline
\end{tabular}

7). The growth of vocal apparatus structures, however, was not independent, but reliable on the body size of the individuals. Thus, when the body size increased, this also increased the vocal apparatus measurements and this was congruent with the canonical discrimination of Functions 1 and 2 of Sarawak ranids (Figure 5). Whereas, significant correlation between variables (Table 7), especially between pvpm with all other vocal apparatus measurements (cpbp, cpep, bplp and lpep) also consistently supported the highest loading on first and second dimensions (Table 3). The length of pvpm, determines the length of the vocal cords on the arytenoids cartilage, also influenced the spectral and temporal call characteristics of the frog.

\section{DISCUSSION}

The variations in size and shape of the vocal apparatus structure of frogs suggest that sexual selection forces by females may correlate with the vocal apparatus components, which enable each frog species emit unique call characteristics. For example, it was suggested in this

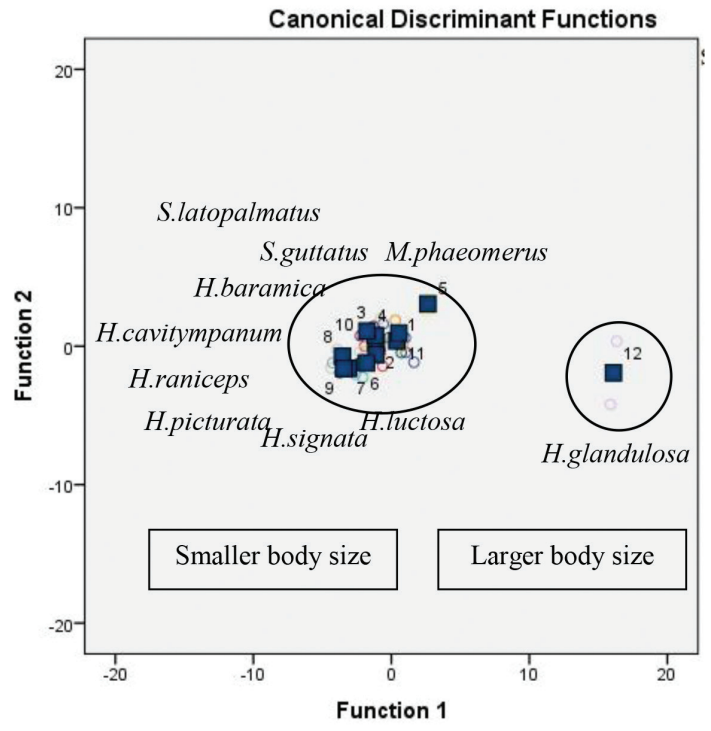

FIGURE 5. Canonical discrimination functions of Functions 1 and 2 for vocal apparatus structure of family Ranidae

TABLE 7. Correlation matrix of Sarawak male ranids based on body size and vocal apparatus measurements

\begin{tabular}{|c|c|c|c|c|c|c|c|c|}
\hline & SVL & PVPM & CPBP & CPEP & BPLP & LPEP & $\mathrm{BP}^{\circ}$ & $\mathrm{LP}^{\circ}$ \\
\hline SVL & - & & & & & & & \\
\hline PVPM & $\begin{array}{c}0.755 * * \\
(0.006)\end{array}$ & - & & & & & & \\
\hline СРBP & $\begin{array}{c}0.800 * * \\
(0.003)\end{array}$ & $\begin{array}{c}0.799 * * \\
(0.003)\end{array}$ & - & & & & & \\
\hline CPEP & $\begin{array}{c}0.755 * * \\
(0.006)\end{array}$ & $\begin{array}{c}0.995 * * \\
(0.000)\end{array}$ & $\begin{array}{c}0.825 * * \\
(0.002)\end{array}$ & - & & & & \\
\hline BPLP & $\begin{array}{l}0.619 * \\
(0.028)\end{array}$ & $\begin{array}{c}0.831 * * \\
(0.001)\end{array}$ & $\begin{array}{c}0.482 \\
(0.079)\end{array}$ & $\begin{array}{c}0.832 * * \\
(0.001)\end{array}$ & - & & & \\
\hline LPEP & $\begin{array}{c}0.826 * * \\
(0.002)\end{array}$ & $\begin{array}{c}0.909 * * \\
(0.000)\end{array}$ & $\begin{array}{c}0.892 * * \\
(0.000)\end{array}$ & $\begin{array}{c}0.929 * * \\
(0.000)\end{array}$ & $\begin{array}{c}0.781 * * \\
(0.004)\end{array}$ & - & & \\
\hline $\mathrm{BP}^{\circ}$ & $\begin{array}{l}-0.345 \\
(0.165)\end{array}$ & $\begin{array}{c}0.202 \\
(0.288)\end{array}$ & $\begin{array}{l}-0.298 \\
(0.202)\end{array}$ & $\begin{array}{c}0.153 \\
(0.337)\end{array}$ & $\begin{array}{c}0.173 \\
(0.316)\end{array}$ & $\begin{array}{l}-0.158 \\
(0.331)\end{array}$ & - & \\
\hline $\mathrm{LP}^{\circ}$ & $\begin{array}{l}-0.046 \\
(0.450)\end{array}$ & $\begin{array}{c}0.448 \\
(0.097)\end{array}$ & $\begin{array}{c}0.193 \\
(0.297)\end{array}$ & $\begin{array}{c}0.426 \\
(0.110)\end{array}$ & $\begin{array}{c}0.132 \\
(0.358)\end{array}$ & $\begin{array}{c}0.107 \\
(0.385)\end{array}$ & $\begin{array}{c}0.774 * * \\
(0.004)\end{array}$ & - \\
\hline
\end{tabular}

$N=10$; Pearson's correlation, $\mathrm{r} ; * *$ Correlation is significant at the 0.01 level (1-tailed); *Correlation is significant at the 0.05 level (1-tailed) 
study that the two empty halls on the vocal apparatus of $H$. luctuosa may function as air storage before allowing the air through the cords. In this way, H. luctuosa could accumulate more energy for the next call. Hence, this causes long gap duration approximately in $60-80 \mathrm{~s}$ to the next call. More energy is needed to produce high frequency call and this could help a successful transmission of the call wavelength to the conspecific through substrates on their microhabitat in nature. As the result, this species emits a single, but increasing note call and recognized as 'meowlike' call recorded by Zainudin et al. (2010a).

The energetic calling property is generated by the enzymatic reaction of muscles which control movement of the arytenoids cartilages during contraction. Zimmitti (1998) proved that trunk muscles of male Pseudacris crucifer had higher enzymatic activities of citrate synthase and $\beta$-hydroxyacyl-CoA dehydrogenase when the males produced higher calling rate relative to larger body size. It has also obviously affected the call properties of $H$. cavitympanum, S. latopalmatus and $M$. phaeomerus in this study. H. cavitympanum was recorded producing an ultrasonic signal in the wild and Arch et al. (2008) showed a series of short pulsed call in the ultrasonic signal. This is strongly correlated with the presence of thick muscles surround the vocal apparatus of this particular species, indicating that there is a positive relationship between muscle thickness and temporal call characteristic, specifically call duration as suggested by McClelland et al. (1996)

The length between pulvinar vocale and posterior margin of the arytenoids cartilage of the Sarawak frogs also corresponds with the way vocal cords vibrate. The vocal cords are a pair of membranous lining derived from the arytenoids cartilage lining and each end of the vocal cord is attached to the inner margin of the cricoids cartilage and the posterior margin of the arytenoids cartilage, respectively. Hence, the larger the size of the vocal apparatus, the longer the distance between these two points (pulvinar vocale and posterior margin), thus resulting in an increased length of the vocal cords. As a consequence, the vibrations that travel in the distance will produce low frequency of sound due to the greater dimension in which the vocal cords need to stretch when the arytenoids cartilage pivot. Therefore, the resultant tension is increased by partial attachment of the vocal cords to the relatively rigid cricoids ring. This confluence is indeed very useful to determine the fundamental frequency of the call produced. This is consistent with Gebler and Frey (2005), suggested that the elongation of vocal cords corresponded with low fundamental frequency.

Larger vocal apparatus size, however, resulted in a lower dominant frequency of the Sarawak frog call characteristics. Clearly, larger structure caused slower movements of the vocal apparatus, hence reducing vibration frequency and lowering the pulse rates. The significant relationship between vocal apparatus structure and body size (SVL) of the Sarawak frogs (Table 6) suggested that the frog's body growth largely reflects variations in vocal apparatus structure and the frog call characteristics and thus indicating that the vocal apparatus does not independently evolve, but reliably on the general body growth. Considering this, the evolution of the bioacoustic communication system in Sarawak ranids is explained in a way that their adaptation traits (variability of vocal apparatus in different species) change allometrically with their body size and their surrounding ecological factors. The availability and competition for basic needs such as food sources and microhabitat preferences as continuity of survivorship may induce the variance of body size on different frog species with their habitat.

The vocal apparatus somehow, functioning as a sound transmitter, releases the sound signal into their environment (via air or water) to their conspecific receiver, hindering a successful communication system among and between frog species. Therefore, abiotic factors also play an important role indirectly altering some of the frog's vocalization properties to conspecific. This is important especially to highly dispersed frog species in Sarawak, for example the Bornean horned frog (Megophrys nasuta) which is widely distributed throughout the Sundaland region, could provide new information on the impact of changing environment to their communication mechanism in Sarawak. Hence, further investigations should be done to examine the relationship of the vocal apparatus structure at population level from different localities. Zainudin et al. (2010b) showed high genetic divergence of the green paddy frog Hylarana erythraea collected from different localities in Sarawak and thus it was hypothesised that frog calls from various localities might also show differences in their call characteristics and vocal apparatus structure due to coevolution of their adaptation traits.

The overall findings of this study were consistent with Boyd et al. (1998) that showed the length and width of male Rana catesbeiana were significantly greater than the female bullfrogs. However, the length of the arytenoids cartilages might not explain complex calls produced by some frog species. Thus, it is also best to examine the lateral passageways of the vocal apparatus as shown by Drewry et al. (1982) that suggested the lateral feature might involve in a mechanism which is responsible for the complex call production. On the other hand, the complexity in call of túngara frog showed strong relation with the laryngeal expansion during vocalization (Stephenson \& Verrell 2003). The findings of this study indicated that vocal apparatus structure varies for each frog species of Sarawak ranids and frog species of the same genus share some similar general shape; the vocal apparatus structure reflects advertisement call characteristics of the frog species with a strong correlation to the body size; and thus this structure is a useful character to discriminate species.

\section{CONCLUSION}

Histochemistry analysis on the tissues of the Sarawak frog's vocal apparatus in this study provides new additional information and extensive understanding of 
the behaviour of Sarawak frogs in the Sundaland region. Consequently, this technique has proved to be a valuable tool for showing the biomechanical nature and functions of the vocal apparatus in the generation of their bioacoustic signals which resulted in different advertisement call characteristics for every species as described in Zainudin et al. (2011). This study is the first documentation of the influence of vocal apparatus structures (shape and size) on highly variables advertisement call characteristics of different frog species in Sarawak. This study also demonstrated that the frog's body growth potentially has implication on the evolution of the frog's vocal apparatus. As the result, variations in the vocal apparatus structures directly affect the call pattern of both spectral and temporal call components for the frog species. The finding also leads us to a better understanding of the selective pressure for specific acoustic recognition of females to select the best quality of males in their social interaction, particularly for successful mating. This specific trait is a good evidence of complex morphological vocal component in different species of frogs, in which, if any modification occurred on the vocal apparatus structures, it could probably alter the frog call properties. This will lead to variance in advertisement call characteristics among populations of the same species, hence this would induce the course of speciation events. Thus, it is recommended that extensive study should be done on other frog species in Sarawak.

\section{ACKNOWLEDGEMENTS}

This project was funded by grants FRGS/01(21)/753/2010(39) and FRGS/STWN10 (02)/987/2013(28). We thank the Department of Sarawak Forestry for the research permit (No.NPW.907.4.4 (Jld.VI)-60) to conduct research at protected areas. Our highest gratitude to UNIMAS staffs that involved during sample collections and laboratory analyses.

\section{REFERENCES}

Arch, V.S., Grafe, T.U. \& Narins, P.M. 2008. Ultrasonic signalling by a Bornean frog. Biology Letters 4: 19-22.

Boyd, S.K., Wissing, K.D., Heinsz, J.E. \& Prins, G.S. 1998. Androgen receptors and sexual dimorphisms in the larynx of the bullfrog. General and Comparative Endocrinology 113: 59-68.

Drewry, G.E., Heyer, W.R. \& Rand, A.S. 1982. A functional analysis of the complex call of the frog Physalaemus pustulosus. Copeia 3: 636-645.

Duellman, W.E. \& Trueb, L. 1986. Biology of Amphibians. London: The John Hopkins University Press.

Fears, B.A.C. 2010. Laryngeal Apparatus and Call Structure in North American Hylids. Masters Science Dissertation. Missouri University of Science and Technology (Unpublished).

Gebler, A. \& Frey, R. 2005. Anatomical structures involved in non-human vocalization. ZAS Papers in Linguistics 40: 33-43.

Inger, R.F. \& Stuebing, R.B. 2005. A Field Guide of the Frogs of Borneo. Kota Kinabalu: Natural History Publications (Borneo) Sdn. Bhd.
Kiernan, J.A. 2008. Histological and Histochemical Methods: Theory and Practice. 4th ed. Bloxham, UK: Scion.

Marquez, R. \& Eekhout, X.R. 2006. Advertisement calls of six species of anurans from Bali, Republic of Indonesia. Journal of Natural History 40: 571-588.

Mason, M.J., Willi, U.B. \& Narins, P.M. 2010. Comments on Tympanic-membrane and malleus-incus-complex coadaptations for high frequency hearing in mammals, edited by Sunil Puria \& Charles Steele. Hearing Research 267(12): $1-3$.

Mason, M.J., Wang, M. \& Narins, P.M. 2009. Structure and function of the middle ear apparatus of the aquatic frog, Xenopus laevis. Proceedings of the Institute of Acoustics Institute of Acoustics (Great Britain) 31: 13-21.

Matsui, M. 1997. Call characteristics of Malaysian Leptolalax with a description of two new species (Anura: Pelobatidae). Copeia 1: 158-165.

McClelland, B., Wilczynski, W. \& Ryan, M.J. 1996. Correlations between call characteristics and morphology in male cricket frogs (Acris crepitans). The Journal of Experimental Biology 199: 1907-1919.

Mescher, A.L. 2010. Junqueira's Basic Histology Text and Atlas. 12th ed. United States: McGrawHill.

Narins, P.M. 2009. Middle ear adaptations for seismic detection in the golden mole. Proceedings of the International Workshop on Bio-inspired Sensing and Bio-inspired Actuation Technology. pp. 36-49.

Ryan, M.J. 1990. Vocal morphology of the Physalaemus pustulosus species group (Leptodactylidae): Morphological response to sexual selection for complex calls. Biological Journal of the Linnean Society 40: 37-52.

Sheridan, J.A., Bickford, D. \& Su, K.F.Y. 2010. An examination of call and genetic variation in three wide-ranging Southeast Asian anuran species. The Raffles Bulletin of Zoology 58(2): 197-207.

Spector, D.L. \& Goldman, R.D. 2006. Basic Methods in Microscopy: Protocols and Concepts from Cells - A Laboratory Manual. New York: Cold Spring Harbor.

Stephenson, B. \& Verrell, P. 2003. Courtship and mating of the tailed frog (Ascaphus truei). Journal of Zoology 259(1): 15-22.

Wollerman, L. 1999. Acoustic interference limits call detection in a Neotropical frog Hyla ebraccata. Animal Behaviour 57: 529-536.

Zainudin, R., Wahid, H.A. \& Rahman, M.A. 2011. Croaks of the Bornean Frog. The Hylarana of Sarawak. Sarawak: University Malaysia Sarawak Publication.

Zainudin, R., Rahman, M.A., Zain, B.M., Nor, S.M., Inger, R.F. \& Ahmad, N. 2010a. Mating calls description of five species of frogs from the genus Hylarana Tschudi 1838 (Amphibia, Anura, Ranidae) from Sarawak, Malaysia. Sains Malaysiana 39(3): 363-369.

Zainudin, R., Nor, S.M., Ahmad, N., Zain, B.M.M. \& Rahman, M.A. 2010b. Genetic structure of Hylarana erythraea (Amphibian: Anura: Ranidae) from Malaysia. Zoological Studies 49(5): 688-702.

Zainudin, R., Rahman, M.A., Mohd Zain, B.M., Nor, S.M., Norhayati, A. \& Inger, R.F. 2009. Ciri-ciri panggilan katak Borneo (Genus: Hylarana) dari populasi Sarawak, Malaysia Timur. Sains Malaysiana 38(5): 619-624.

Zimmitti, S.J. 1998. Individual Variation and Sexual Dimorphism in Traits Related to Call Production in the Spring Peeper (Pseudacris crucifer). Masters Science Dissertation, University of Connecticut, Storrs (Unpublished). 
Elvy Quatrin Deka \& Ramlah Zainudin*

Department of Zoology

Faculty of Resource Science and Technology

Universiti Malaysia Sarawak

94300 Kota Samarahan, Sarawak Bumi Kenyalang Malaysia

Lela Su'ut

Department of Pathology

Faculty of Medicine and Health Science

Universiti Malaysia Sarawak

94300 Kota Samarahan, Sarawak Bumi Kenyalang

Malaysia
Hasnizam Abdul Wahid

Department of Music

Faculty of Applied and Creative Arts

Universiti Malaysia Sarawak

94300 Kota Samarahan, Sarawak Bumi Kenyalang

Malaysia

*Corresponding author; email: zramlah@frst.unimas.my

Received: 1 April 2014

Accepted: 24 May 2015 